Article

\title{
Cigarette and Cannabis Smoking Effects on GPR15+ Helper T Cell Levels in Peripheral Blood: Relationships with Epigenetic Biomarkers
}

\author{
Allan M. Andersen ${ }^{1, *(\mathbb{D})}$, Man-Kit Lei ${ }^{2,3}$ (), Steven R. H. Beach ${ }^{3,4}$, Robert A. Philibert ${ }^{1,5}$, \\ Sushmita Sinha ${ }^{6}$ and John D. Colgan ${ }^{7,8} \mathbb{D}$

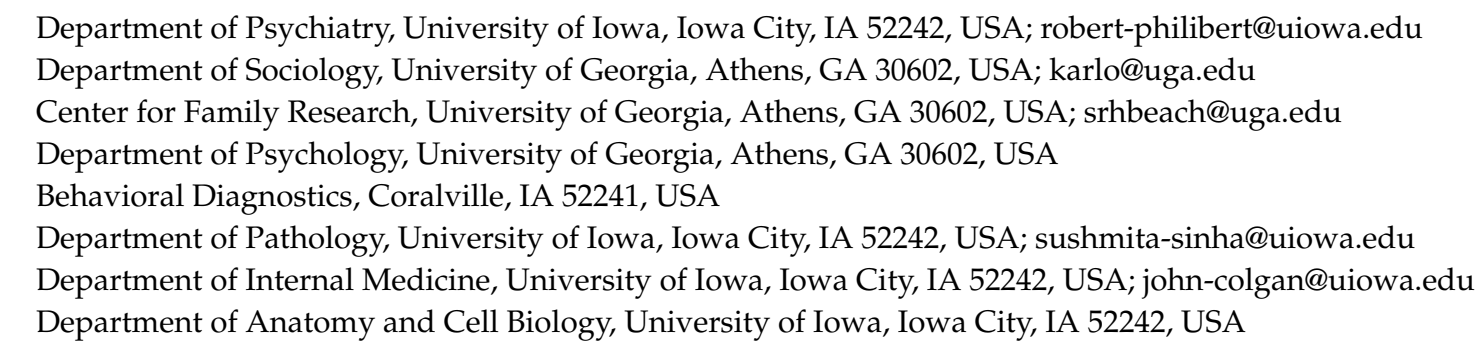

Received: 15 January 2020; Accepted: 27 January 2020; Published: 30 January 2020

\begin{abstract}
Background: Smoking causes widespread epigenetic changes that have been linked with an increased risk of smoking-associated diseases and elevated mortality. Of particular interest are changes in the level of T cells expressing G-protein-coupled receptor 15 (GPR15), a chemokine receptor linked with multiple autoimmune diseases, including inflammatory bowel disease, multiple sclerosis and psoriasis. Accordingly, a better understanding of the mechanisms by which smoking influences variation in the GPR15+ helper T cell subpopulation is of potential interest. Methods: In the current study, we used flow cytometry and digital PCR assays to measure the GPR15+CD3+CD4+ populations in peripheral blood from a cohort of $n=62$ primarily African American young adults (aged 27-35 years) with a high rate of tobacco and cannabis use. Results: We demonstrated that self-reported tobacco and cannabis smoking predict $\mathrm{GPR} 15^{+} \mathrm{CD}^{+} \mathrm{CD}^{+}$helper $\mathrm{T}$ cell levels using linear regression models. Further, we demonstrated that methylation of two candidate CpGs, cg19859270, located in GPR15, and cg05575921, located in the gene Aryl Hydrocarbon Receptor Repressor (AHRR), were both significant predictors of GPR $15^{+} \mathrm{CD}^{+} \mathrm{CD}^{+}$cell levels, mediating the relationship between smoking habits and increases in GPR $15^{+} \mathrm{CD}^{+} \mathrm{CD}^{+}$cells. As hypothesized, the interaction between $\operatorname{cg} 05575921$ and $\operatorname{cg} 19859270$ was also significant, indicating that low cg05575921 methylation was more strongly predictive of GPR $15^{+} \mathrm{CD}^{+} \mathrm{CD}^{+}$cell levels for those who also had lower cg19859270 methylation. Conclusions: Smoking leads changes in two CpGs, cg05575921 and cg19859270, that mediate $38.5 \%$ of the relationship between tobacco and cannabis smoking and increased GPR $15^{+} \mathrm{T}_{\mathrm{h}}$ levels in this sample. The impact of cg19859270 in amplifying the association between cg05575921 and increased GPR15 ${ }^{+} \mathrm{T}_{\mathrm{h}}$ levels is of potential theoretical interest given the possibility that it reflects a permissive interaction between different parts of the adaptive immune system.
\end{abstract}

Keywords: biomarkers; epigenetics; smoking; tobacco; cannabis; digital PCR

\section{Introduction}

Smoking is the leading cause of preventable morbidity and mortality in the United States, and is responsible for nearly half a million deaths per year [1,2]. Chronic illnesses with inflammatory components, including cancer [3], chronic obstructive pulmonary disease (COPD), cardiovascular 
disease (CVD), and stroke [4] contribute to the majority of deaths caused by smoking. Smokers also suffer from elevated rates of autoimmune diseases including Crohn's disease [5], rheumatoid arthritis [6], and multiple sclerosis [7], as well as elevated rates of inflammatory skin and gut disorders [8,9]. Unfortunately, the pathophysiologic mechanisms underlying smoking's relationships to these diseases are not yet well understood. One approach to better understanding these mechanisms is to identify mediators of the effects of smoking on key systemic regulators known to influence disease outcomes. In particular, effects mediated by smoking's well-established effects on DNA methylation are promising.

In the current investigation, we chose to focus on an understudied systemic effect of smoking, i.e., its impact on levels of CD3+CD4+ helper $\mathrm{T}\left(\mathrm{T}_{\mathrm{h}}\right)$ cells expressing the G-protein-coupled receptor 15 (GPR15), a chemokine receptor encoded by the chromosome 3 gene GPR15. Originally identified as a coreceptor for simian immunodeficiency virus (SIV), human immunodeficiency virus 2 (HIV-2), and some human immunodeficiency virus 1 (HIV-1) strains [10-12], GPR15 has been linked to multiple smoking-associated diseases, including rheumatoid arthritis [13], inflammatory bowel disease [14-16], and multiple sclerosis [17], and psoriasis [18].

Recently, interest in the relationship between smoking and GPR $15^{+} \mathrm{T}_{\mathrm{h}}$ cells has increased as a result of multiple epigenome-wide studies of studies demonstrating associations between smoking and hypomethylation of cg19859270, a CpG located in the first exon of GPR15 [19-23]. Bauer and colleagues $[24,25]$ provided insight into this association by demonstrating two findings. First, smokers had a highly significant $\left(p=1.8 \times 10^{-10}\right)$ increase in the peripheral $C D 3^{+} \mathrm{T}$ cells expressing GPR15 $(15.5 \%$ in smokers vs. $3.7 \%$ in non-smokers), and to a lesser extent $\mathrm{B}$ cells, and second, these GPR $15^{+} \mathrm{CD}^{+} \mathrm{T}$ cells had a markedly lower average methylation of cg19859270 than GPR15- ${ }^{-}{ }^{+} 3^{+} \mathrm{T}$ cells, resulting in the arithmetic difference in mean methylation at cg19859270 observed in whole blood.

Interestingly, smoking-associated hypomethylation of cg19859270 appears to be more pronounced in individuals of African Ancestry. In one study of 972 African Americans [21], cg19859270 was the second most highly smoking-associated locus in the epigenome, while in two other African American cohorts cg19859270 was the first and second most strongly associated probe, respectively [26,27]. In contrast, cg19859270 was not among the top 25 smoking-associated CpGs in a large meta-analysis of smoking-associated CpG sites in which the majority (76\%) of included individuals were of European Ancestry [28]. One reason for these discrepant results may be cis genetic variants that moderate methylation status at cg19859270 and whose frequencies are ethnically contextual, such as rs2230344 (minor allele frequency in African Americans is 0.06; in Europeans, 0.23) [27].

A second methylation locus of potential relevance in understanding smoking-associated changes in GPR15 ${ }^{+} \mathrm{T}_{\mathrm{h}}$ cell levels is cg05575921, located in the chromosome 6 gene Aryl Hydrocarbon Receptor Repressor (AHRR). In addition to being perhaps the most well-replicated finding in environmental epigenetics [23,28-30], smoking-associated hypomethylation of cg05575921 is a highly sensitive and specific indicator of smoking status, with Receiver Operating Characteristic (ROC) areas under the curve (AUC) as high as 0.99 reported [22,31,32]. Underlying cg05575921's strong performance as a biomarker, as well as the reliability of its association with smoking, is its large "delta beta", i.e., the magnitude of difference in methylation in smokers compared to non-smokers. Whereas most smoking-associated CpGs demonstrate delta betas of less than 10\%, in heavy smokers methylation at cg05575921 may be $50 \%$ or more below the population average of around $85 \%-90 \%$ [30]. This large dynamic range also facilitates the measurement of dose-response effects [28,33-35] and reversibility of cg05575921 hypomethylation associated with smoking cessation [36-39].

Smoking-associated changes in methylation at cg05575921 may also provide insight into biological responses to smoking. Specifically, the methylation status of it is thought to influence expression of AHRR [22], a key regulator of the xenobiotic pathway responsible for detoxification of polyaromatic hydrocarbons found in tobacco and cannabis smoke [40] that has also been shown to influence inflammatory responses and act as a tumor suppressor gene in several types of cancers [41]. Cg05575921 hypomethylation has also been directly linked to elevated systemic inflammation, as indicated by 
serum C-reactive protein (CRP) [42], and an increase in overall mortality risk [43,44]. Lastly, in contrast to cg19859270, smoking-associated hypomethylation of cg05575921 is not influenced by genetic background, providing additional utility as a tool for investigating smoking's biological effects in populations of mixed ancestry [28]. Lastly, in contrast to cg19859270, hypomethylation of cg05575921 has been shown in multiple studies to primarily occur in granulocytes and monocytes, suggesting a distinct role for these cell populations in biological responses to smoking $[45,46]$.

Although concern that GPR15+ T cells may be drivers of chronic inflammatory disease processes in smokers [47], their physiological role and the exact nature of their relationship to smoking remain unclear. Kim [48] found that mice deficient in GPR15 developed severe large intestinal inflammation, suggesting a potentially protective role in immune homeostasis, while Bauer and colleagues [49] found that the level of GPR15-expressing T cells was unrelated to the lung disease status in human smokers and non-smokers. Bauer and colleagues [45] also found that smoking was associated with increased GPR15 expression across a broad range of $T$ cell subtypes in adults, suggesting GPR15+ T cells may be adaptive rather than pathogenic.

In addition to questions as to the therapeutic value of interventions targeting GPR15+ T cells in human smokers at risk for inflammatory disease, relationships between smoking patterns, GPR15 expression, and other immunological variables remain unclear. In particular, the differential impact of tobacco vs. cannabis smoking patterns on GPR15 expression in T cells has not been previously explored but is of potential significance given the anti-inflammatory effects of some cannabinoids [50]. In examining this relationship, other immunological variables of potential impact include psychological factors influencing the HPA axis [51], adiposity [52], non-steroidal anti-inflammatory drug (NSAID) use [53], and ancestry. The latter factor may be of particular relevance both because of the strong link between smoking and hypomethylation of cg19859270 in African Americans, reviewed above, and from a public health perspective because African Americans bear a disproportionate burden of smoking-associated illnesses $[54,55]$ and demonstrate higher levels of systemic inflammation than European American smokers [56].

Lastly, it is unknown whether the net effect of the above factors on variance in T cells expressing GPR15 is fully accounted for by changes in methylation at cg19859270 and cg05575921, respectively indicating the transcriptional status of GPR15 and systemic exposure to smoke, and whether interactions between the methylation status of these two CpGs can account for additional variance in this cell population.

Here, we examine those relationships using novel digital PCR methods in a cohort of African Americans young adults with a high rate of smoking, testing the following hypotheses:

1. First, we examine whether the proportion of GPR15-expressing CD3+CD4+ $T_{h}$ cells is associated with (a) tobacco and cannabis smoking patterns and (b) confounding variables that could impact immune function such as age, sex, race, perceived stress, depressive symptomatology, and use of over-the-counter non-steroidal anti-inflammatory drugs (NSAIDs).

2. Second, we examine whether the addition of cg19859270 and cg05575921 can fully account for the variance in the level of GPR15-expressing $\mathrm{CD}^{+} \mathrm{CD}^{+} \mathrm{T}_{\mathrm{h}}$ cells due to smoking patterns and other immunological variables.

3. Third, we examine whether interaction effects between cg19859270 and cg05575921 influence the level of GPR15-expressing $\mathrm{CD}^{+} \mathrm{CD}^{+} \mathrm{T}_{\mathrm{h}}$ cells.

\section{Materials and Methods}

\subsection{Sample}

The Family and Community Health Study (FACHS) is a mulita-site investigation of neighborhood and family effects on child health and development, consisting of several hundred African American families living in Georgia and Iowa. Each family who participated in the FACHS study included at least one child subject between the ages of 10 and 12 years old at the time of recruitment (1995-1997). 
Child subjects have been characterized over seven waves of data collection since the beginning of the study. Later waves of FACHS have also included subjects' romantic partners, who along with the subjects themselves consented to be recontacted for future studies. A more detailed description of the FAHCS sample and methods for the study is available elsewhere [57-59].

\subsection{Subject Procedures}

Participants in the current study included FACHS subjects (now adults in their early 30s) and romantic partners, currently living in Iowa who participated in the last wave of the study (wave seven, collected 2014-2016), and had agreed to be recontacted for future studies. Study subjects were recruited by phone by a trained research assistant and provided written consent to participate.

Subjects were administered a brief, structured interview on their use of tobacco products, cannabis products, and other nicotine-containing products, including e-cigarettes. Next, to allow for analyses controlling for common factors that may impact immune function, subjects then completed three structured self-report forms. First, they were asked to report on their average consumption of over-the-counter NSAIDs. Second, subjects completed a nine-item Patient Health Questionnaire depression module (PHQ-9) [60], and third, a Perceived Stress Scale [61]. Subjects then provided self-reported data on their ethnicity (African American or other), age, height, and weight for calculation of body-mass index (BMI) as a proxy for adiposity, the latter due its potential impact on immune function [62].

All study protocols and procedures were approved by the Institutional Review Board at the University of Iowa (Title: Tobacco and Cannabis Smoking Effects on Immune Function in Youth; IRB ID \# 201604748).

\subsection{Biomaterials and Assays}

Following completion of data collection, subjects were phlebotomized to provide whole blood for DNA preparation and flow cytometry assays, and sera, according to our previously published protocols [31,63].

\subsubsection{ELISAs}

Serum cotinine and tetrahydrocannabinol (THC) levels were assayed by enzyme-linked immunoassay (ELISA) with kits supplied by Abnova (Taiwan) as previously described [31].

\subsection{2. ddPCR Assays}

Determination of the methylation status at cg05575921 and cg19859270 was conducted using ddPCR implementation of the previously described quantitative PCR approach [26]. First, $1 \mu \mathrm{g}$ of DNA from each subject was bisulfite converted using an EpiTect Fast 96 DNA Bisulfite kit (Qiagen, Germany) according to the manufacturer's direction.

The methylation ratio at cg05575921 (C/(C+T)) in each bisulfite treated sample was then determined using the Smoke Signature ${ }^{\circledR}$ Assay (IBI Scientific, Peosta, IA, USA) and a QX200 Droplet Digital PCR System $^{\mathrm{TM}}$ (Bio-Rad, Hercules, CA, USA) according to the manufacturer's protocols. In brief, an aliquot of the bisulfite-converted DNA was pre-amplified with the Smoke Signature®Pre-Amp Master Mix under high stringency conditions per the manufacturer's protocol, and then diluted between 1:1000 and 1:5000. Then, $5 \mu \mathrm{L}$ of the resulting solution was mixed with $1.1 \mu \mathrm{L}$ of 20X Smoke Signature Assay, $6.5 \mu \mathrm{L}$ of water, and $11 \mu \mathrm{L}$ of BioRad 2X ddPCR Supermix (no dUTP), and vortexed.

The resulting mixture was then processed with a Bio Rad Automated Droplet Generator, which generated approximately 20,000 micelles, with each containing approximately 1 nanoliter of PCR mixture, and PCR amplified $\left(95^{\circ} \mathrm{C} \times 10^{\prime}\right.$, then 40 cycles of $95^{\circ} \mathrm{C} \times 15^{\prime \prime}$ and $55^{\circ} \mathrm{C} \times 60^{\prime \prime}$, and finally $\left.98^{\circ} \mathrm{C} \times 10^{\prime}\right)$. After amplification was complete, the post-amplification allele content status (either $\mathrm{C}, \mathrm{T}$, $\mathrm{C}+\mathrm{T}$, or blank) of each micelle was determined by a QX200 Droplet Reader and the percent methylation status of each sample calculated using BioRad's QuantaSoft software (v1.7) (BioRad: Hercules, CA, 
USA). The methylation ratio at cg19859270 was similarly determined using a custom-designed primer and probe ddPCR assay for the sequence surrounding the $\mathrm{CpG}$, following identical procedures to those described for cg05575921. Primer and probe sequences are available in File S5.

\subsubsection{PBMC Isolation and Cryopreservation}

Peripheral blood mononuclear cells (PBMCs) were isolated using Vacutainer CPT tubes from Becton Dickinson (BD; Franklin Lakes, NJ, USA) according to the manufacturer's protocol. Immediately following isolation, PBMCs were cryopreserved in liquid nitrogen in a solution of $10 \%$ DMSO, $20 \%$ fetal calf serum, 70\% RPMI supplemented with HEPES (1M, pH range 7.2-7.5) and L-glutamine via slow temperature-lowering method with a Mr. Frosty Nalgene polyethylene vial holder (Thermo Fisher Scientific, San Jose, CA, USA) containing isopropyl alcohol.

Cells were stored in liquid nitrogen for $>=1$ week before thawing. Prior to staining, PBMCs were rapidly thawed in a solution of $10 \%$ fetal calf serum, $90 \%$ RPMI supplemented with DNAse in a $37{ }^{\circ} \mathrm{C}$ water bath. Samples were washed in FACS buffer (1X PBS containing 1\% BSA and $0.1 \%$ sodium azide). Viability and recovery were measured using tryptan blue exclusion.

\subsubsection{Flow Cytometry}

Following washing in FACS buffer, PBMCs were stained with anti-CD3 (clone UCHT1, BD), anti-CD4 (monoclonal, clone Sk3, BD), and either anti-GPR15 (clone SA302A10, BioLegend, San Diego, CA, USA)) or a mouse IgG2a kappa isotype control (clone MOPC-2710, BioLegend). Samples were resuspended in $100 \mu \mathrm{L}$ of FACS buffer for staining and were stained with $1 \mu \mathrm{L}$ of each antibody as per the manufacturer's recommendations. Samples were acquired on a Becton Dickinson LSR II flow cytometer using FACS Diva Software. Fully stained PBMCs were compared with unstained samples and samples stained with IgG2a kappa isotype control. The percent of $\mathrm{CD}^{+} \mathrm{CD}^{+} \mathrm{T}$ cells staining positive for GPR15 (hereafter "GPR15 ${ }^{+} \mathrm{T}_{\mathrm{h}}$ cell percent") for each subject was visualized and calculated using FlowJo software version 7 (Tree Star, San Carlos, CA, USA).

\subsection{Statistical Analysis}

Statistical analyses were conducted with the R [64] statistical software. The complete dataset used for the analyses below is included as Table S6.

\subsubsection{Coding}

Self-report data on tobacco, cannabis, and nicotine-containing products were coded as follows. Subjects who endorsed any use of combusted tobacco or cannabis products within a given time frame (week, month, year, or ever) were coded as positive for a derived variable reflecting any smoke inhalation over that time period. Similarly, subjects who endorsed any use of nicotine-containing products, including tobacco products and e-cigarettes, were coded as positive for nicotine use over that time period, and subjects who endorsed any use of cannabis were coded positive for cannabis use over the same time period.

Intensity of cannabis use was coded based on subjects' self-reported use of cannabis over the past year. Due to high variability in how subjects reported their use of cannabis, units of one "blunt" and one "joint" were each coded as equal a $0.5 \mathrm{~g}$ dose of cannabis. Cumulative consumption of cannabis in grams over the last year was then coded on a 0 to 2 scale, with 0 reflecting no use in the past year, 1 less than $50 \mathrm{~g}$ consume in the past year, and 2 reflecting $50 \mathrm{~g}$ or more consumed in the past year. For tobacco use, due to the infrequency of use of tobacco products other than cigarettes, intensity was coded as the numeric average cigarettes per day consumed.

Perceived Stress Scale and PHQ-9 total scores were calculated according to published instructions. Subjects reported their dose and frequency use of three NSAIDs: ibuprofen, aspirin, and naproxen, which were then converted to equipotent doses of ibuprofen $200 \mathrm{mg}$ [65]. 
Serum cotinine levels of $1 \mathrm{ng} / \mathrm{mL}$ or greater were coded as positive for the purposes of analysis. Similarly, serum THC levels of $0.5 \mathrm{ng} / \mathrm{mL}$ or greater were coded as positive. An additional variable was derived reflecting positivity for either cotinine or THC or being negative for both.

\subsubsection{Correlational Analyses}

Correlational analyses were used to examine the relationship between self-reported smoking of both tobacco and cannabis, methylation of cg05575921 and cg19859270, and other subject characteristics using the function rcorr(). The same analyses were then repeated including only subjects concordant for any self-reported smoking (tobacco and/or cannabis) and any serum positivity (cotinine and/or THC). Visualization of correlations between study variables was done using the corrplot() function in $\mathrm{R}$.

\subsubsection{ANOVAs}

The significance of differences in mean levels of methylation at cg05575921, cg19859270, and GPR15 ${ }^{+} \mathrm{T}_{\mathrm{h}}$ cell percent between groups were measured by ANOVA using the aov() function. Post hoc testing was done by Tukey's method using the TukeyHSD() function.

\subsubsection{Regression Analyses}

Multiple regression analyses were used to examine the effect of self-reported smoking intensity of tobacco and/or cannabis on the GPR15 ${ }^{+} \mathrm{T}_{\mathrm{h}}$ cell percent, with and without covariates that could potentially impact immune cell function and proliferation. Of note, we use the term "prediction" in to refer to linear predictors in the context of multiple regression modeling, rather than to indicate validation of these models in a second dataset.

To examine methylation at cg05575921 and cg19859270 as potential mediators of the association between self-reported smoking and GPR15 ${ }^{+} \mathrm{T}_{\mathrm{h}}$ cell percent, the two CpGs were entered in conjunction with the other predictors to examine whether these methylation signatures could account for the impact of smoking on GPR15 ${ }^{+} \mathrm{T}_{\mathrm{h}}$ cell percent, reducing the observed effect of self-reported smoking and confounders to non-significance. Then, to explore the potential for interaction between the two CpGs to account for additional variance in GPR15 ${ }^{+} T_{h}$ cell percent, methylation values for each CpG were centered and normalized, with the interaction of the resulting variables then entered as an additional predictor in the regression model.

The above models were then repeated on a subset of subjects demonstrating concordance for tobacco or cannabis smoking (self-report and serum positivity) or non-use (self-report and serum negativity) to more stringently examine the above hypotheses.

Next, to examine the specific effects of tobacco and cannabis smoking on GPR15 ${ }^{+} \mathrm{T}_{\mathrm{h}}$ cell percent, dummy variables tobacco-only smoke exposure and cannabis-only smoke exposure in the last year were added to the above models, Subjects were coded as "tobacco-only" if they were positive for self-reported tobacco smoking (cigarette or cigar) in the last year, or demonstrated serum cotinine positivity, and were negative for both self-reported cannabis smoking and serum THC. Similarly, "cannabis-only" subjects had endorsed cannabis smoking or demonstrated serum THC positivity but could not have self-reported any tobacco smoking in the last year or were positive for serum cotinine.

Lastly, to examine the relative contributions of cg05575921, cg19859270, and their interaction term as predictors of GPR15 ${ }^{+} \mathrm{T}_{\mathrm{h}}$ cell percent, the three predictors were entered into a linear regression model which was then analyzed using the Relative Importance of Regressors in Linear Models package, relaimpo(), [66] using the method of partitioning $\mathrm{R}^{2}$ by averaging over orders ("1mg"). 


\section{Results}

\subsection{Subject Characteristics and Assay ResuLts}

Contact information was available for a total of 169 FACHS young adult subjects living in Iowa who had agreed to be recontacted for future studies. Of these, 81 were contacted and agreed to participate in the study.

Subject demographic characteristics, clinical variables, and laboratory results and their correlations are summarized in Table 1. Consistent with the nature of the cohort, a longitudinal study of subjects enrolled in 5th grade starting in 1996, there was a tight age distribution around 31 years. The majority of subjects were African Americans, with a preponderance of females. Notably, subjects had a high rate of obesity, with the majority of body mass index (BMI) values calculated at over thirty. Most subjects rated their level of depressive symptomatology between the minimal and moderate ranges [60], while average stress levels were reported as higher than the population average [61]. Sixty percent of subjects reported smoking cigarettes at some point in their lives, while 77\% reported at least one use of cannabis. Serum enzyme-linked immunoassays (ELISAs) of cotinine and tetrahydrocannabinol (THC) were completed for 71 subjects.

Table 1. Means and standard deviations for study variables, all subjects $(n=62)$.

\begin{tabular}{lcc}
\hline \multicolumn{1}{c}{ Variable } & M & SD \\
\hline 1. Age (years) & 30.7 & 1.2 \\
2. Gender (male) & 0.37 & - \\
3. Race (African American) & 0.86 & - \\
4. Body mass index (BMI) & 34.0 & 8.5 \\
5. Perceived Stress Scale & 19.3 & 4.4 \\
6. PHQ-9 total & 4.7 & 4.1 \\
7. NSAID daily dose & 0.43 & 1.00 \\
8. Any smoking (past year) & 0.55 & 0.50 \\
9. Cannabis use (past month) & 0.32 & 0.47 \\
10. Nicotine use (past week) & 0.31 & 0.47 \\
11. Cotinine positivity & 0.31 & 0.47 \\
12. THC positivity & 0.32 & 0.47 \\
13. cg19859270 methylation & 93.4 & 2.4 \\
14. cg05575921 methylation & 70.3 & 16.7 \\
15. GPR15+ \% (CD3+/CD4+) & 5.7 & 5.0 \\
\hline
\end{tabular}

BMI refers to body mass index. Perceived stress scale refers to the Perceived Stress Scale total score. PHQ-9 refers to the Patient Health Questionnaire depression module total score. Nonsteroidal anti-inflammatory drug (NSAID) daily dose refers to $200 \mathrm{mg}$ equivalent doses of ibuprofen, naproxen, and aspirin. Any smoking indicates exposure to tobacco and/or cannabis smoke. Cotinine positivity indicates serum values of $>1 \mathrm{ng} / \mathrm{mL}$, while tetrahydrocannabinol (THC) positivity indicates $>0.5 \mathrm{ng} / \mathrm{mL}$.

A total of 65 subjects had both cg05575921 and cg19859270 digital droplet PCR (ddPCR) assays completed. Two subjects failed quality control for the cg19859270 ddPCR assay, defined as greater than a 5\% confidence interval for the methylation value, while no subjects failed the cg05575921 assay, leaving a total of 63 subjects with both ddPCR assays available for analysis. Lastly, flow cytometry experiments to measure the percent of $\mathrm{CD}^{+} \mathrm{CD}^{+} \mathrm{T}$ cells staining positive for GPR15 (hereafter "GPR15 ${ }^{+} \mathrm{T}_{\mathrm{h}}$ cell percent") were completed for 62 of those 63 subjects, leaving a total of 62 subjects for whom all measures were completed.

\subsection{Study Variable Correlations}

Correlations between study variables are depicted in Figure 1 and are available in Table S1. Results of serum ELISA assays for cotinine and THC indicated an overall high rate of current cannabis use $(32 \%)$ and nicotine-containing products (31\%), with $44 \%$ of subjects positive for one or both. 


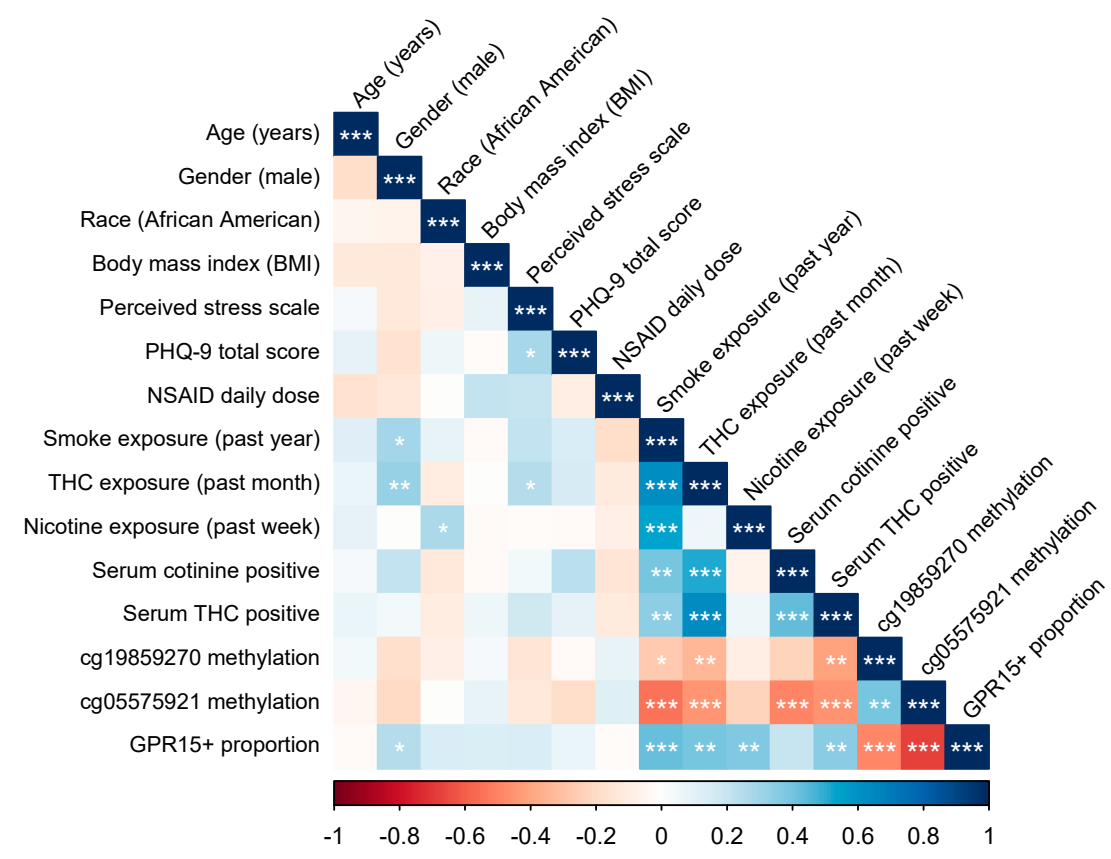

Figure 1. Correlations between study variables analyzed. BMI refers to body mass index. Perceived Stress Scale refers to the Perceived Stress Scale total score. PHQ-9 refers to the Patient Health Questionnaire depression module total score. Nonsteroidal anti-inflammatory drug (NSAID) daily dose refers to $200 \mathrm{mg}$ equivalent doses of ibuprofen, naproxen, and aspirin. Smoke exposure indicates tobacco and/or cannabis smoking. Serum cotinine positive indicates serum values of $>1 \mathrm{ng} / \mathrm{mL}$, while serum tetrahydrocannabinol (THC) positive indicates $>0.5 \mathrm{ng} / \mathrm{mL}$. GPR15+ proportion refers to the proportion of CD3+CD4+ PBMCs. Significance codes: * $p \leq 0.05 ;{ }^{* *} p \leq 0.01 ;{ }^{* * *} p \leq 0.001$.

Interestingly, subject self-reports of cannabis use were strongly associated with serum THC positivity $\left(\mathrm{r}=0.631, p=3.86 \times 10^{-8}\right)$, whereas prior-week use of nicotine containing products was uncorrelated with serum cotinine positivity $(\mathrm{r}=-0.062, p=0.630)$. This may reflect differences in THC and cotinine persistence, cotinine assay problems, patterns of episodic use in this sample, or differences in accuracy of self-reporting. To control for the latter possibility, primary linear regression analyses were rerun using only participants with biochemically confirmed use.

Digital PCR assays for cg19859270 and cg05575921 indicated a range of methylation values similar to other studies with a mix of smokers and non-smokers [25,37], with cg05575921 demonstrating the greater dynamic range, as previously reported [30]. Methylation values at the two CpGs were moderately correlated with each other $(R=0.395, p=0.00149)$. Both CpGs were correlated with self-reported tobacco smoking, cannabis smoking, and serum THC positivity, while serum cotinine positivity was strongly correlated with cg05575921 methylation but only showed a trend association with cg19859270, as depicted in Figure 1 and detailed in Table S1.

The distribution of methylation values for cg05575921 and cg19859270, conditioned on (1) self-reported smoking of either tobacco or cannabis products in the last year and (2) serum positivity for either cotinine or THC, is depicted in Figure 2. 
A

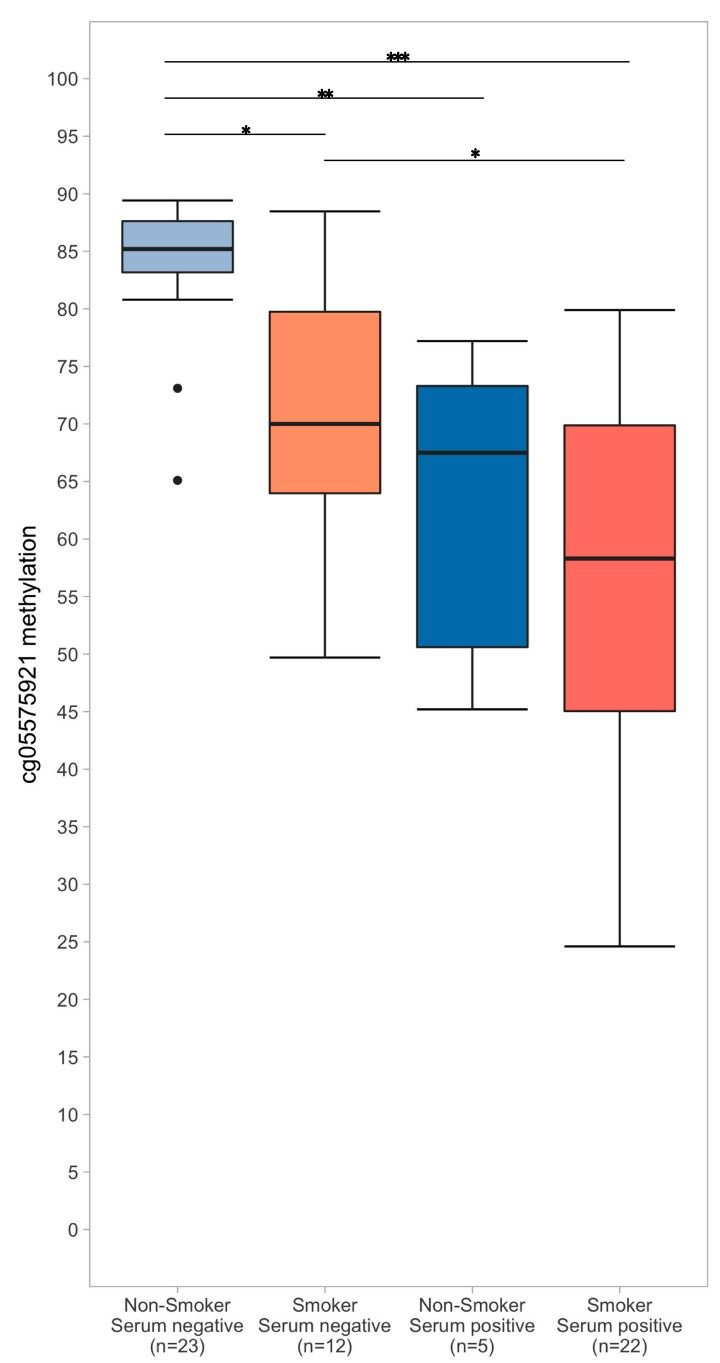

B

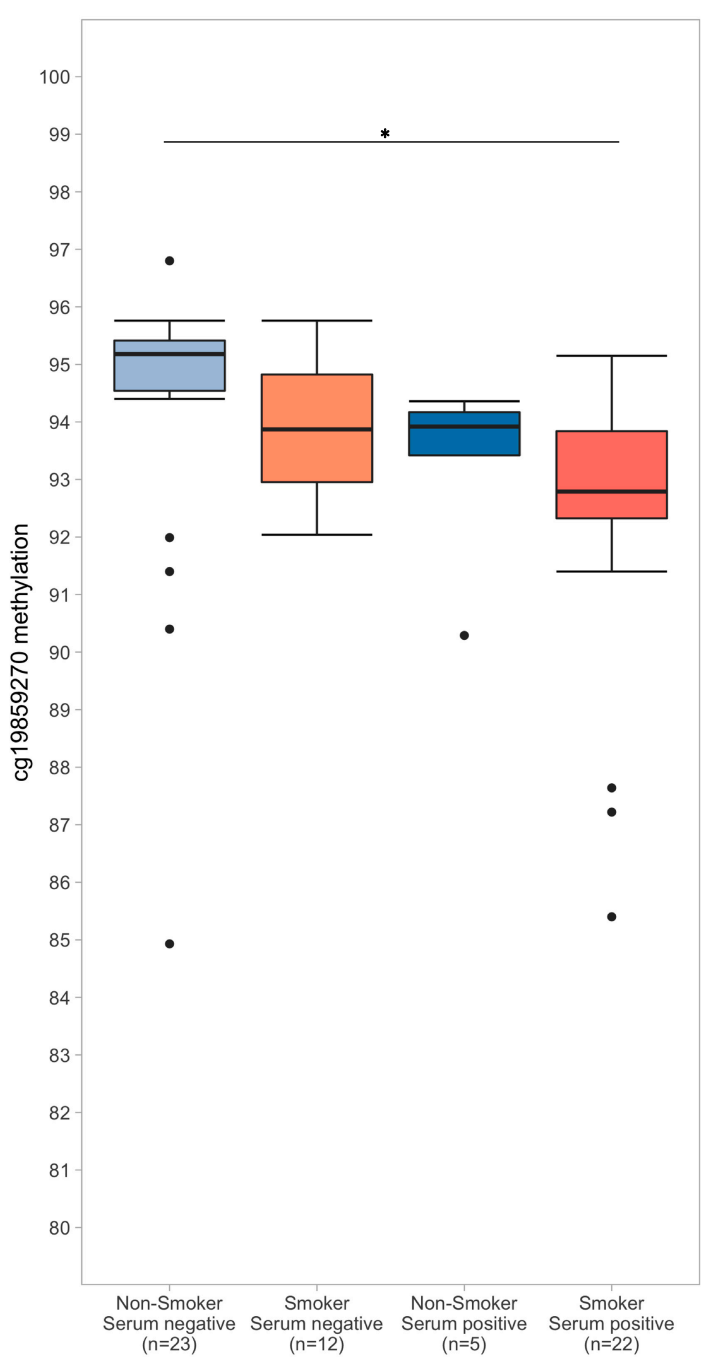

Figure 2. Boxplots of cg05575921 (A) and cg19859270 (B) methylation stratified by self-reported smoking status (tobacco and/or cannabis) and serum positivity (cotinine $>1 \mathrm{ng} / \mathrm{mL}$ and/or tetrahydrocannabinol (THC) $>0.5 \mathrm{ng} / \mathrm{mL}$ ). Significance codes: ${ }^{*} p \leq 0.05 ;{ }^{* *} p \leq 0.01$; ${ }^{* *} p \leq 0.001$ (Tukey's Honest Significant Difference).

The flow cytometry gating strategy used to measure GPR15+ Th cell percent is depicted in Figure 3 A. Across all subjects, GPR15 ${ }^{+} \mathrm{T}_{\mathrm{h}}$ cell percent ranged from 0.60 to 31.60 , with a mean of 5.71 (SD 5.04). Subjects positive for cotinine or THC had a mean GPR15 ${ }^{+} \mathrm{T}_{\mathrm{h}}$ cell percent of 8.33 (SD 5.92) with a range of 2.12 to 31.6, while those negative for both cotinine and THC had a mean of 3.67 (SD 3.00) and a range of 0.60 to 12.4 . GPR $15^{+} \mathrm{T}_{\mathrm{h}}$ cell percent was significantly correlated with male gender, self-reported smoking in the past year, cannabis smoking in the past month, nicotine use in past week, serum THC status, and both cg05575921 and cg19859270, as shown in Figure 1 and Table S1, but not with other subject characteristics.

For comparison, a correlation table for the study variables including only the $n=45$ subjects concordant for self-reported smoking (tobacco and/or cannabis) and serum indicators (serum cotinine and/or THC) was constructed, otherwise including the same variables as in Table S1. As seen in Table S2, characteristics of subjects who were concordant for self-reported use versus non-use of cigarettes and cannabis were similar to the group as a whole, with the exception that correlations between epigenetic and serum biomarkers were strengthened. 
A
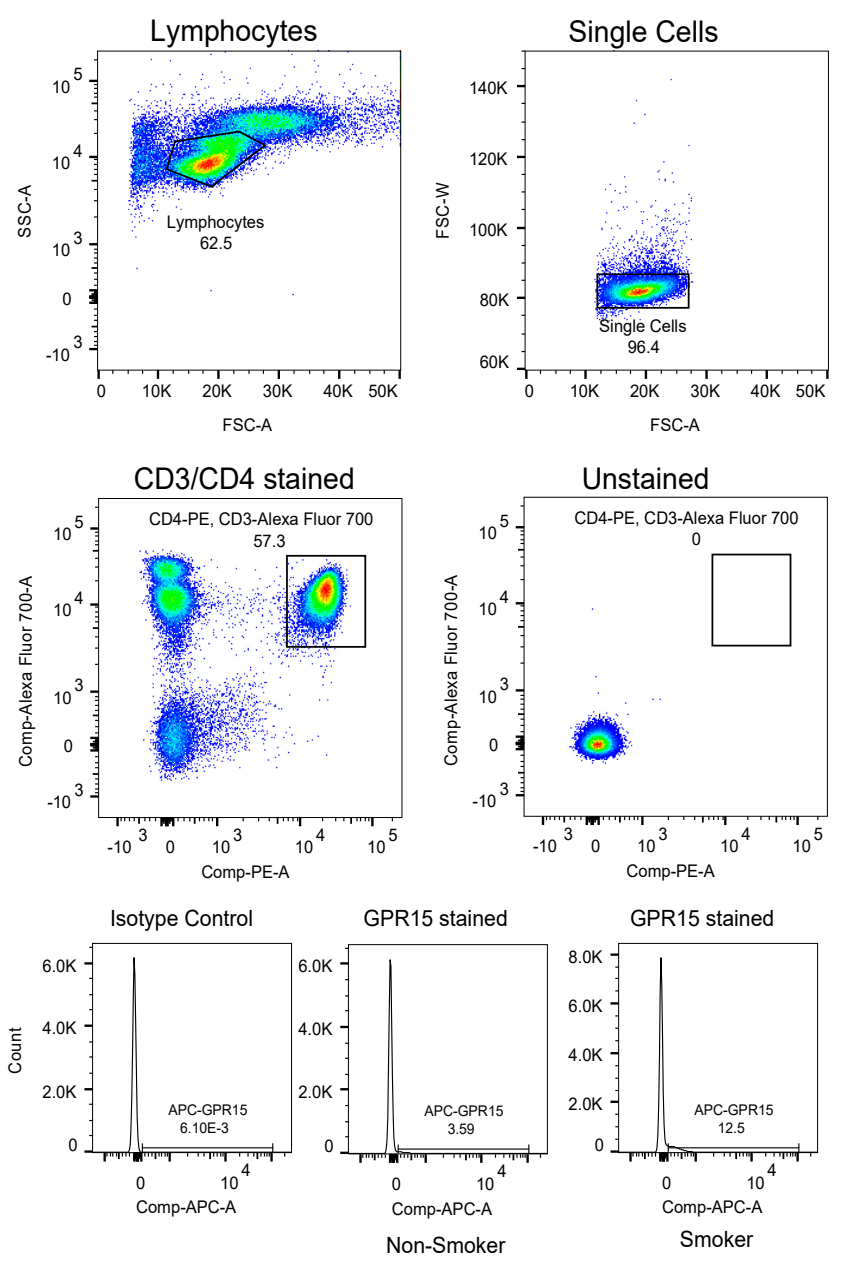

B
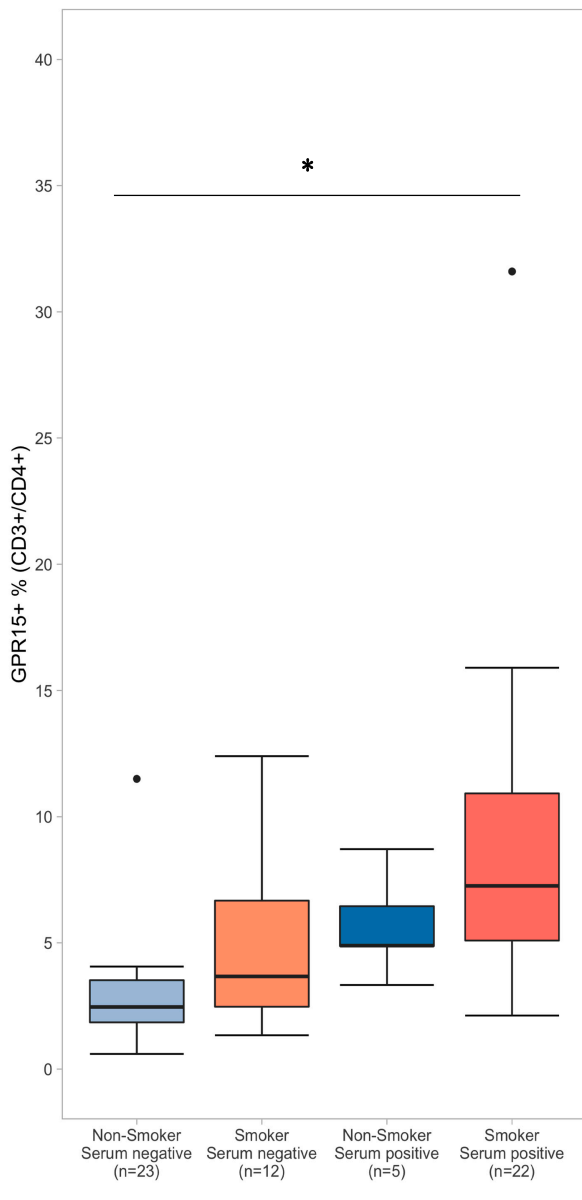

Figure 3. GPR15+ Th cell flow cytometry gating strategy and results stratified by smoking status and serum positivity. Panel (A) depicts the flow cytometry gating strategy used to visualize GPR $15^{+} \mathrm{T}_{\mathrm{h}}$ cell percent within the $\mathrm{CD}^{+} \mathrm{CD}^{+}$population of peripheral lymphocytes. Histograms at bottom depict $\mathrm{GPR}^{+} 5^{+} \mathrm{T}_{\mathrm{h}}$ cell percent data from two subjects, one a "non-smoker", negative for both self-reported smoking and serum cotinine and tetrahydrocannabinol (THC), and the other a "smoker", positive for self-reported smoking and both cotinine and THC. The leftmost histogram depicts the results from the same "non-smoker" using the mouse IgG2a kappa isotype as a negative control. Panel (B) depicts boxplots of $\mathrm{T}_{\mathrm{h}}$ cell percent for subjects stratified by self-reported smoking status (tobacco and/or cannabis) and serum positivity (cotinine $>1 \mathrm{ng} / \mathrm{mL}$ and/or THC $>0.5 \mathrm{ng} / \mathrm{mL}$ ). Significance codes: ${ }^{*} p \leq 0.05 ;{ }^{* *} p \leq 0.01 ;{ }^{* * *} p \leq 0.001$ (Tukey's Honest Significant Difference).

\subsection{Regression Analysis Results}

Multiple linear regression models were used to examine the relationships between smoking behavior, DNA methylation, changes in GPR $15^{+} \mathrm{T}_{\mathrm{h}}$ cell percent, with and without covariates that could potentially affect immune function and proliferation, and also to examine mediational hypotheses.

First, GPR15 $5^{+} \mathrm{T}_{\mathrm{h}}$ cell percent was regressed against two variables reflecting self-reported intensity of cigarette and cannabis smoking, respectively, as shown in Table 2. The first model (Model 1A) demonstrated that both cigarettes per day and scaled cannabis use over the last year were significant predictors of GPR $15^{+} \mathrm{T}_{\mathrm{h}}$ cell percent with an $\mathrm{R}^{2}$ of $0.357\left(p=4.18 \times 10^{-7}\right)$. The addition of predictors potentially impacting immune composition and function (Model 1B) did not further improve model fit. In contrast, the subsequent addition of cg05575921 and cg19859270 (Model 1C) did improve the fit $\left(\mathrm{R}^{2}=0.590, p=1.52 \times 10^{-8}\right)$. Interestingly, while both CpGs were significant predictors of GPR $15^{+} \mathrm{T}_{\mathrm{h}}$ 
cell percent in Model 1C, cigarettes per day, though not average cannabis use, remained a significant predictor $(p<0.01)$, indicating that the impact of intensity of self-reported cigarette use was not fully mediated by the two candidate CpGs. Lastly, the interaction term for cg05575921 and cg19859270 was introduced (Model 1D), yielding a significant effect $(p<0.001)$ and improved model fit $\left(\mathrm{R}^{2}=0.670\right.$, $\left.p=2.21 \times 10^{-10}\right)$, while cigarettes per day remained a significant predictor $(p<0.01)$ of GPR15 $5^{+} \mathrm{T}_{\mathrm{h}}$ cell percent. Although BMI was a significant $(p=0.05)$ predictor of GPR $15^{+} \mathrm{T}_{\mathrm{h}}$ cell percent in models $1 \mathrm{C}$ and 1D, a post-hoc linear regression analysis including BMI as a sole predictor did not show a significant relationship with GPR15 ${ }^{+} \mathrm{T}_{\mathrm{h}}$ cell percent $(p=0.282)$. Mediation analysis of Models 1B-1D using the simple path model equation indicated that the two CpGs mediated $35.51 \%$ of the variance in GPR15 ${ }^{+} T_{h}$ cell percent due to cigarettes per day, and $38.53 \%$ with the addition of their interaction term.

Table 2. Multiple linear regression results for GPR15+ Th cell percent regressed against tobacco and cannabis smoking intensity.

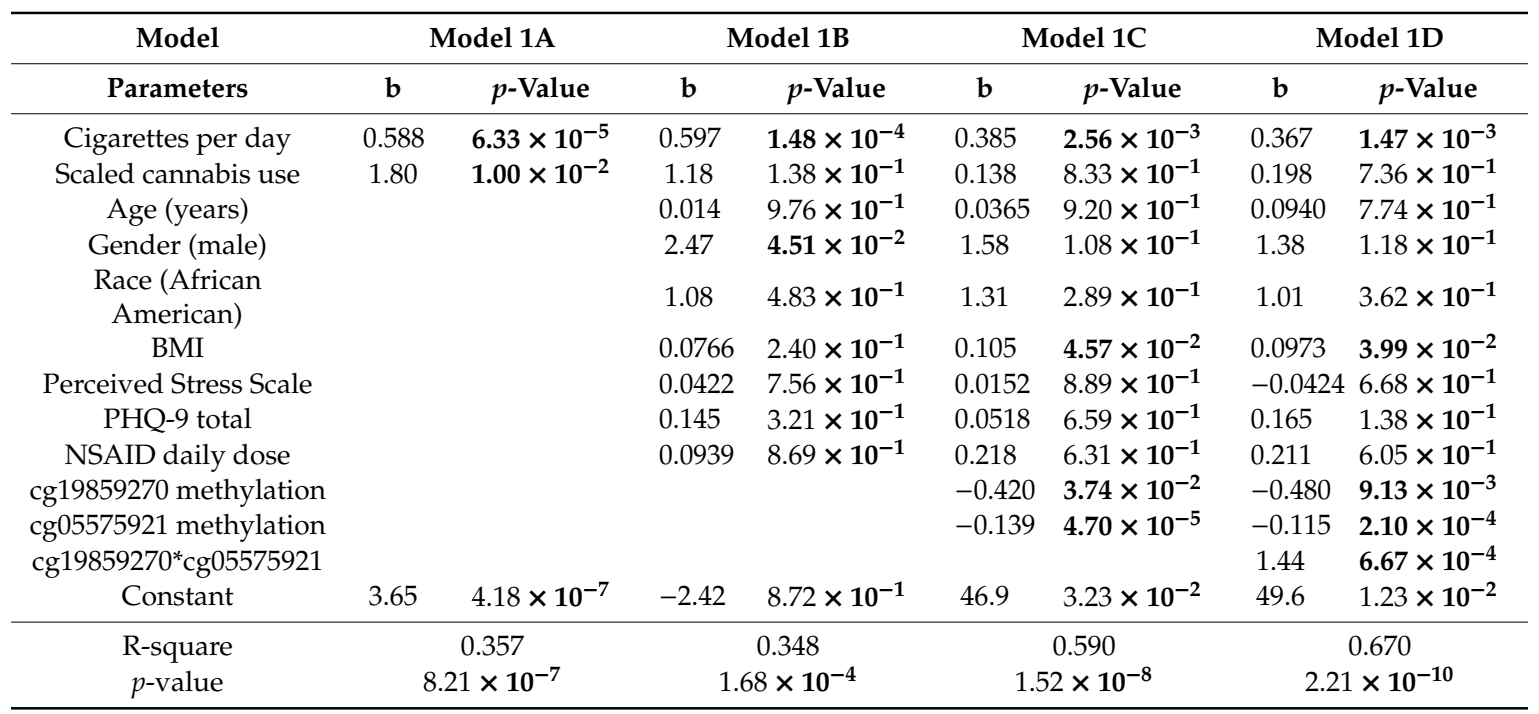

Cigarettes per day calculated by average consumption over the past month. Scaled cannabis use indicates average use over the past year. BMI refers to body mass index. Perceived Stress Scale refers to the Perceived Stress Scale total score. PHQ-9 refers to the Patient Health Questionnaire depression module total score. Nonsteroidal anti-inflammatory drug (NSAID) daily dose refers to $200 \mathrm{mg}$ equivalent doses of ibuprofen, naproxen, and aspirin. Cotinine positivity indicates serum values of $>1 \mathrm{ng} / \mathrm{mL}$, while THC positivity indicates $>0.5 \mathrm{ng} / \mathrm{mL}$. GPR15+ proportion refers to the proportion of CD3+CD4+ PBMCs. Regression results shown for all subjects $(n=62)$. Note: the $\operatorname{cg} 19859270^{*} \operatorname{cg} 05575921$ was centered and normalized prior to entry into the regression model.

To more stringently examine the above relationships, equivalent models were run restricting to the $\mathrm{n}=45$ subjects demonstrating concordance between self-reported smoking intensity (tobacco and/or cannabis) and serum indicators (serum cotinine and/or THC). As shown in Table S3, the full model incorporating both CpGs and their interaction term as predictors (Model 2D) demonstrated the best overall fit, with an $\mathrm{R}^{2}$ of $0.779\left(p=1.83 \times 10^{-9}\right)$. Similar to the above results, the interaction term between the two CpGs was a significant predictor $(p<0.001)$ and improved the significance of cg19859270 as a predictor $(p<0.05)$, while cg05575921 $\left(p=5.30 \times 10^{-5}\right)$ and cigarettes per day $(p<0.01)$ also remained significant predictors of GPR $15^{+} \mathrm{T}_{\mathrm{h}}$ cell percent.

A third set of regression analyses were performed to explore specific effects of tobacco vs. cannabis smoking on GPR15 ${ }^{+} \mathrm{T}_{\mathrm{h}}$ cell percent. As shown in Table S4, the addition of dummy variables indicating tobacco-only smoking ( $\mathrm{n}=10$ subjects) and cannabis-only smoking ( $n=9$ subjects) in the last year did not improve model fit compared to Model 1A (Model 3A, $R^{2}=0.370, p=3.50 \times 10^{-6}$ ), nor did the addition of immunologic variables (Model 3B, $R^{2}=0.344, p=4.16 \times 10^{-4}$ ). The addition of the two CpGs as predictors did improve fit (Model 3C, $R^{2}=0.585, p=7.38 \times 10^{-8}$ ), as did the addition of their interaction term (Model 3D, $R^{2}=0.666, p=1.35 \times 10^{-9}$ ), similar to models $1 \mathrm{C}$ and $1 \mathrm{D}$. Variables indicating tobacco-only and cannabis-only smoking were not significant predictors of GPR15 ${ }^{+} \mathrm{T}_{\mathrm{h}}$ cell 
percent in any of the above models, whereas cigarettes per day but not average cannabis use remained a significant predictor in the full model $(p<0.05)$. Similarly, although the tobacco-only subjects had a higher mean GPR15 ${ }^{+} \mathrm{T}_{\mathrm{h}}$ cell percent $(7.3$, SD 4.4) than the cannabis-only smokers $(4.6,3.0)$, the difference was not significant $(p=0.13)$, nor did the two groups demonstrate significantly different mean levels of $\operatorname{cg} 05575921$ methylation $(p=1)$ or $\operatorname{cg} 19859270$ methylation $(p=1)$.

Given the consistent findings that methylation of $\operatorname{cg} 19859270$ interacted with $\operatorname{cg} 05575921$ to predict GPR15 ${ }^{+} \mathrm{T}_{\mathrm{h}}$ cell percent, this interaction was plotted as the effect of high (+1 SD) versus low (-1 SD) cg19859270 methylation values on the relationship between cg05575921 methylation and GPR15 ${ }^{+} \mathrm{T}_{\mathrm{h}}$ cell percent, as depicted in Figure 4. As demonstrated in the figure and by the corresponding regression model (Model 2D), low cg19859270 methylation intensified the effect of decreasing cg05575921 methylation, reflective of increasing smoke exposure, on expansion of the $\mathrm{GPR}^{+} 5^{+}$population of $\mathrm{CD}^{+} \mathrm{CD}^{+} \mathrm{T}_{\mathrm{h}}$ cells.

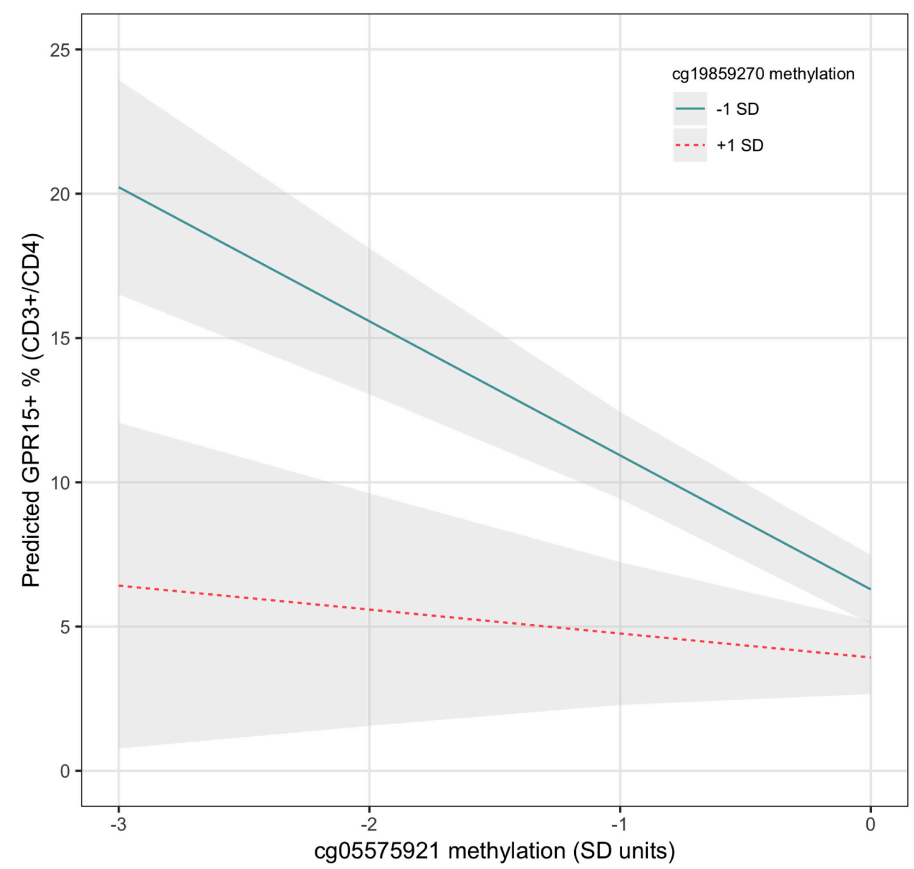

Figure 4. Interaction of cg05575921 and cg19859270 methylation in predicting GPR15 ${ }^{+} \mathrm{T}_{\mathrm{h}}$ cell percent. The interaction is visualized by plotting regression lines for cg05575921 while holding the value of cg19859270 at 1 SD above and below its mean. Regression coefficient values are taken from Model 2D, Table S3. The ribbons indicate the model-based 95\% confidence intervals for each regression line.

Lastly, to examine the relative contributions of cg05575921, cg19859270, and their interaction term as linear predictors of GPR $15^{+} \mathrm{T}_{\mathrm{h}}$ cell percent, the three terms were entered into a linear regression model which was then analyzed using the relaimpo() package in $\mathrm{R}$ using the default settings, $n=1000$ bootstraps. The overall model was significant $\left(R^{2}=0.583, p=1.09 \times 10^{-11}\right)$, as was each predictor individually. The relative contributions of cg05575921 was greatest at $36.2 \%$ (95\% CI $23.4 \%-36.2 \%)$, followed by $\operatorname{cg} 19859270$ at $14.9 \%(2.4 \%-36.2 \%)$, and their interaction term at $9.3 \%(0 \%$ to $22.7 \%)$. The same procedure was then performed using the full model (Model 1D) including smoking intensity variables and immunologic predictors in addition to the two CpGs and their interaction term. Results of that analysis were similar, showing a relative contribution of cg05575921 of $27.9 \%(15.5 \%-44.3 \%)$, $\operatorname{cg} 19859270$ of $11.5 \%(2.9 \%-30.0 \%)$, and their interaction term of $7.4 \%(0 \%-16.1 \%)$. The contribution of cigarettes per day was $13.8 \%(4.1 \%-27.7 \%)$ and scaled marijuana use was $4.8 \%(1.4 \%-11.6 \%)$, while the remaining predictors all contributed less than $3 \%$ of the variance individually. 


\section{Discussion}

Smoking is associated with increased morbidity and mortality. Although the mechanisms underlying this risk are not fully understood, smoking-associated increases in GPR15-expressing immune cells are implicated in a number of illnesses that affect smokers. However, their biological role and mechanisms underlying their strong association with smoking are not well understood.

In this study, we examined a cohort of young African Americans, over half of whom reported lifetime exposure to tobacco and cannabis smoke, exploring differential effects of tobacco and cannabis smoking on GPR15 ${ }^{+} \mathrm{T}_{\mathrm{h}}$ cell percent in the context of other immunological variables and epigenetic indicators of smoking, using a series of multiple linear regression models. We confirmed the association between increased GPR15 ${ }^{+} \mathrm{T}_{\mathrm{h}}$ cell percent and smoking habits found by Bauer and others [25,49] finding independent effects of cigarette and cannabis smoking intensity in our preliminary model, suggesting additive effects of tobacco and cannabis smoke exposure. However, after accounting for other immunological variables, the significant main effect of cannabis smoke exposure was reduced to non-significance. This finding was confirmed by supplemental analyses including analyses focused on biochemically confirmed tobacco-only smokers, cannabis-only smokers, and non-smoking controls.

The addition of epigenetic indicators of smoking, i.e., decreased methylation at cg05575921 and cg19859270, substantially improved prediction of GPR15 ${ }^{+} \mathrm{T}_{\mathrm{h}}$ cell percent in the context of our regression models, consistent with our hypotheses that these two methylation loci reflect both systemic exposure to smoke and the transcriptional status of GPR15, but did not fully account for self-reported smoking's association with GPR15 $5^{+} \mathrm{T}_{\mathrm{h}}$ cell percent, with cigarettes per day remaining a significant predictor. This finding suggests that smoking intensity influences GPR15 ${ }^{+} \mathrm{T}_{\mathrm{h}}$ cell percent through mechanisms not fully captured by the methylation state of two CpGs or other variables measured. This finding is consistent with prior work by Andersen and colleagues [32], who demonstrated that self-report of smoking habits, when accurate, performed approximately equally as well as measurement of cg05575921 methylation in predicting serum cotinine status, but that the combination of both self-report and cg05575921 methylation was overall most predictive.

We hypothesized that ancestry, particularly African American ancestry, might influence the relationship between smoking and GPR15 ${ }^{+} \mathrm{T}_{\mathrm{h}}$ cell percent. In particular, Dogan and colleagues [27] previously demonstrated that rs2230344, the only common non-synonymous SNP in the immediate region of cg19859270, showed a significant main effect on the relationship between smoking status and cg19859270 methylation in African Americans, though not in European Americans. In our study, we were unable to genotype subjects to confirm this effect but did not find an effect of ancestry when entered in conjunction with other predictors. It is unclear whether the ascertainment of rs2230344 genotype in addition to methylation status at cg05575921 and cg19859270 would greatly improve the ability to predict GPR15 levels, although this hypothesis could be readily tested in future investigations.

Although a minor effect of BMI on GPR15 ${ }^{+} \mathrm{T}_{\mathrm{h}}$ cell percent was seen in Model 1C and 1D, the effect was not present prior to the introduction of the two CpGs and their interaction term to the regression model, nor was it seen in models restricted to subjects concordant for self-reported smoking habits and serum indicators of smoking. This inconsistent finding could be an artifact of our relatively small sample size, or might be the result of negative correlations among the predictors, but nonetheless suggests that controlling for BMI may be important in future studies examining the relationship between smoking, GPR15 ${ }^{+} \mathrm{T}_{\mathrm{h}}$ levels, and inflammatory disease, particularly given prior reports linking obesity with elevated of C-reactive protein $[67,68]$. Other potentially confounding demographic and behavioral variables that could affect immune composition and function did not significantly contribute to GPR15 ${ }^{+} \mathrm{T}_{\mathrm{h}}$ cell percent, although larger studies in the future could uncover more subtle effects.

The finding that greater hypomethylation of cg19859270 amplified the relationship between smoke exposure, as indicated by cg05575921 hypomethylation, and GPR $15^{+} \mathrm{T}_{\mathrm{h}}$ cell percent is consistent with expectations that decreased methylation of exonic CpGs facilitates greater gene expression. The mechanism underlying significant interaction between cg05575921 and cg19859270 is not clear but may be influenced by several factors. Because hypomethylation of cg05575921 and cg19859270 
in whole blood have been shown to be linked with more pronounced hypomethylation in distinct immune cell populations, specifically monocytes and granulocytes (cg05575921) and T and B cells (cg19859270) [24,46], one possibility is that the effect observed may therefore indicate unmeasured interactions between these cell populations.

In this context, it should be noted that methylation of the promoter region of methylene tetrahydrofolate reductase (MTHFR) was recently shown to influence smoking-induced hypomethylation of both cg05575921 [69] and cg19859270 [70]. In fact, cg19859270 was the locus most highly influenced by MTHFR promoter methylation across the genome $\left(p=9.04 \times 10^{-15}\right)$ in the study of Andersen and colleagues [32]. This suggests the availability of donor methyl groups for DNA methylation, DNA replication, and other cellular processes may be an additional unmeasured factor in our study influencing GPR15 ${ }^{+} \mathrm{T}_{\mathrm{h}}$ cell percent.

Although they have been associated with a variety of inflammatory conditions, the biological role of GPR15+ expressing T cells is not clear. Bauer [45] and colleagues recently demonstrated that GPR15 expression was not specific to any $T$ cell subtype, although it was most expressed on $T_{h} 17$ cells, and suggested a potentially protective role for GPR15-expressing T cells in chronic smoking. Going forward, further mechanistic studies are needed to establish whether GPR15-expressing T cells convey risk, benefit, or neither in smokers and whether they may be targets for therapeutic interventions.

If relevant to health, measurement of GPR15+ $\mathrm{T}$ cell levels directly by flow cytometry may be the most appropriate in clinical settings. In contrast, accurate estimation of the GPR15+ T cell levels by epigenetic assays requires analysis of a large number of CpGs to accurately estimate cell proportions [71]. While this information may be obtained through the use of a genome-wide chip such as the Illumina 450k, this assay is costlier and time consuming than flow cytometry. The custom designed digital PCR probes used in this study, by comparison, are significantly less costly (we estimate under $\$ 10$ in reagents per sample), but do not provide cell proportion data. However, the use of such probes may be useful in large-scale studies where DNA but not peripheral blood samples suitable for flow cytometry are available, and the cost of genome-wide array-based assays may be prohibitive.

Several unexpected findings in our study are worth noting. First, we observed that a number of our subjects with the greatest GPR $15^{+} \mathrm{T}_{\mathrm{h}}$ cell percent did not demonstrate serum cotinine positivity. Examination of our dataset (available in Table S5) shows that most of these subjects were either positive for serum THC or self-reported recent tobacco or cannabis smoking. Similarly, a single individual who was negative for self-report of both tobacco and cannabis use, and negative for serum cotinine and THC had a GPR15 ${ }^{+} \mathrm{T}_{\mathrm{h}}$ cell percent above $5 \%$. However, examination of this data point showed evidence of hypomethylation of cg05575921, consistent with chronic smoke exposure. Lastly, it is interesting that the subject with the most hypomethylation of cg19859270 was in the serum negative, self-report negative group, and showed a cg05575921 methylation value within the non-smoking range (88\%). Taken together these findings highlight the utility of obtaining complementary sources of information regarding substance use habits and the potential for assay failure.

Because the relatively small sample size examined in the current study is a limitation, replication in an independent sample is needed to confirm whether the combination of digital PCR assays for cg05575921 and cg19859270 truly improves prediction of GPR15 ${ }^{+} \mathrm{T}_{\mathrm{h}}$ cell percent. The small sample size may have also obscured other significant contributions to GPR15 ${ }^{+} \mathrm{T}_{\mathrm{h}}$ cell percent such as cannabis-specific smoking patterns, and ethnicity, particularly the low number of non-African Americans in our sample. Second, as discussed above, because we were unable to control for cell type proportions in our analyses, caution is warranted in interpretation of our results, and future experiments with cell proportion data are needed to confirm our findings. Third, the small amount of variability of cg19859270 compared to cg05575921 or direct measurement of GPR $15^{+} \mathrm{T}_{\mathrm{h}}$ cell percent suggest that it has little utility as an independent biomarker for smoking. Fourth, a low rate of cotinine positivity in the subjects with the greatest GPR $15^{+} \mathrm{T}_{\mathrm{h}}$ cell percent suggests that poor ELISA assay performance may have impacted our results, despite strong correlations between cotinine positivity and cg05575921 methylation. 


\section{Conclusions}

In conclusion, we have demonstrated that two smoking-associated CpGs, cg05575921 and cg19859270, and their interaction, mediate a substantial portion (38.5\%) of the relationship between tobacco smoking and increased GPR $15^{+} \mathrm{T}_{\mathrm{h}}$ levels in the context of multiple linear regression models. In addition, the impact of cg05575921 demethylation on GPR15+Th levels was amplified by cg19859270, suggesting the possibility of enhanced prediction of cell level using only these two smoking-associated CpGs. The impact of cg19859270 in amplifying the association between cg05575921and increased GPR15 ${ }^{+} T_{h}$ levels is of potential theoretical interest given the possibility that it reflects a permissive interaction between different parts of the adaptive immune system. Because GPR $15^{+} \mathrm{T}_{\mathrm{h}}$ levels have suggestive links with smoking-associated diseases, further efforts to define its biological role in both smokers and non-smokers are needed. Our results suggest that it may be feasible to estimate GPR15 ${ }^{+}$ $\mathrm{T}_{\mathrm{h}}$ cell levels in settings where direct measurement of GPR15 ${ }^{+} \mathrm{T}_{\mathrm{h}}$ cells are not possible, such as large DNA biobanks.

Supplementary Materials: The following are available online at http://www.mdpi.com/2073-4425/11/2/149/s1. Table S1. Correlations: means, and standard deviations for study variables, all subjects $(n=62)$, Table S2. Correlations, means, and standard deviations for study variables, restricting to cotinine/THC verified subjects $(n=45)$, Table S3. Multiple linear regression results for GPR15+ Th cell percent regressed against tobacco and cannabis smoking intensity, restricting to cotinine/THC verified subjects $(n=45)$. Smoking intensity indicated by cigarettes per day and a scaled average of cannabis use over the past year. Additional predictors include cg05575921 methylation, cg19859270 methylation, a cg05575921* cg19859270 interaction term, and demographic and behavioral covariates regressed on GPR15+ Th cell percent. Note: the cg19859270* $\operatorname{cg} 05575921$ was centered and normalized prior to entry into the regression model, Table S4. Multiple linear regression results for GPR15+ Th cell percent regressed against tobacco and cannabis smoking intensity with dummy variables indicating tobacco-only smoking $(n=10)$ and cannabis-only smoking $(n=9)$. Smoking intensity indicated by cigarettes per day and a scaled average of cannabis use over the past year. Additional predictors include cg05575921 methylation, cg19859270 methylation, a cg05575921* cg19859270 interaction term, and demographic and behavioral covariates. Note: the cg19859270* $\mathrm{cg} 05575921$ was centered and normalized prior to entry into the regression model, File S6. Cg19859270 digital PCR assay primer and probe sequences, and Table S6. Dataset used for all analyses including biological assays, self-report data, demographic variables and behavioral measures.

Author Contributions: J.D.C., S.S., and R.A.P. contributed to the methods used in the study. A.M.A. obtained funding and collected and characterized the subjects in the study, conducted the experiments, and wrote the initial draft of the manuscript. A.M.A., S.R.H.B., and M.-K.L., contributed to statistical analyses. A.M.A., J.D.C., S.S., R.A.P., S.R.H.B., and M.-K.L. All contributed to interpretation of findings and critical revisions of the manuscript. All authors have read and agreed to the published version of the manuscript.

Funding: A.A. is supported by K12DA000357. R.P. is supported by R44 CA213507, R44AA022041 and R01DA037648. The content is solely the responsibility of the authors and does not necessarily represent the official views of the National Institutes of Health. The funders had no role in study design, data collection and analysis, decision to publish, or preparation of the manuscript.

Acknowledgments: The data presented herein were obtained at the Flow Cytometry Facility, which is a Carver College of Medicine/Holden Comprehensive Cancer Center core research facility at the University of Iowa. The facility is funded through user fees and the generous financial support of the Carver College of Medicine, Holden Comprehensive Cancer Center, and Iowa City Veteran's Administration Medical Center.

Conflicts of Interest: The funders had no role in the design of the study; in the collection, analyses, or interpretation of data; in the writing of the manuscript, or in the decision to publish the results. The use of DNA methylation to assess smoking status is covered by US patent $8,637,652$ and other pending claims. Philibert is a potential royalty recipient on those intellectual right claims. Philibert is also an officer and stockholder of Behavioral Diagnostics. (www.bdmethylation.com).

\section{References}

1. DHHS. The Health Consequences of Smoking-50 Years of Progress: A Report of the Surgeon General; National Center for Chronic Disease Prevention and Health Promotion Office on Smoking and Health: Atlanta, GA, USA, 2014. Available online: https://aahb.org/Resources/Pictures/Meetings/2014-Charleston/PPT\% 20Presentations/Sunday\%20Welcome/Abrams.AAHB.3.13.v1.o.pdf (accessed on 27 January 2020).

2. Jamal, A.; Phillips, E.; Gentzke, A.S.; Homa, D.M.; Babb, S.D.; King, B.A.; Linda, J.N. Current cigarette smoking among adults-United States, 2016. Morb. Mortal. Wkly. Rep. 2018, 67, 53-59. [CrossRef] [PubMed] 
3. Fantini, D.; Seiler, R.; Meeks, J.J. Molecular footprints of muscle-invasive bladder cancer in smoking and nonsmoking patients. In Urologic Oncology: Seminars and Original Investigations; Elsevier: Amsterdam, The Netherlands, 2018; pp. 818-825.

4. Mokdad, A.H.; Marks, J.S.; Stroup, D.F.; Gerberding, J.L. Actual causes of death in the United States, 2000. Jama 2004, 291, 1238-1245. [CrossRef] [PubMed]

5. Ng, S.C.; Bernstein, C.N.; Vatn, M.H.; Lakatos, P.L.; Loftus, E.V.; Tysk, C.; O’Morain, C.; Moum, B.; Colombel, J.F. Geographical variability and environmental risk factors in inflammatory bowel disease. Gut 2013, 62, 630-649. [CrossRef] [PubMed]

6. Chang, K.; Yang, S.M.; Kim, S.H.; Han, K.H.; Park, S.J.; Shin, J.I. Smoking and rheumatoid arthritis. Int. J. Mol. Sci. 2014, 15, 22279-22295. [CrossRef] [PubMed]

7. Riise, T.; Nortvedt, M.W.; Ascherio, A. Smoking is a risk factor for muLtiple sclerosis. Neurology 2003, 61, 1122-1124. [CrossRef]

8. Freiman, A.; Bird, G.; Metelitsa, A.I.; Barankin, B.; Lauzon, G.J. Cutaneous effects of smoking. J. Cutan. Med. Surg. 2004, 8, 415-423. [CrossRef]

9. Mahid, S.S.; Minor, K.S.; Soto, R.E.; Hornung, C.A.; Galandiuk, S. (Eds.) Smoking and Inflammatory Bowel Disease: A Meta-Analysis. Mayo Clinic Proceedings; Elsevier: Rochester, MN, USA, 2006.

10. Edinger, A.L.; Hoffman, T.L.; Sharron, M.; Lee, B.; O’Dowd, B.; Doms, R.W. Use of GPR1, GPR15, and STRL33 as coreceptors by diverse human immunodeficiency virus type 1 and simian immunodeficiency virus envelope proteins. Virology 1998, 249, 367-378. [CrossRef]

11. Krumbiegel, M.; Kirchhoff, F. Coreceptor usage of BOB/GPR15 and Bonzo/STRL33 by primary isolates of human immunodeficiency virus type 1. J. Gen. Virol. 1999, 80, 1241-1251.

12. Blaak, H.; Boers, P.; Gruters, R.; Schuitemaker, H.; Van Der Ende, M.; Osterhaus, A. CCR5, GPR15, and CXCR6 are major coreceptors of human immunodeficiency virus type 2 variants isolated from individuals with and without plasma viremia. J. Gen. Virol. 2005, 79, 1686-1700. [CrossRef]

13. Cartwright, A.; Schmutz, C.; Askari, A.; Kuiper, J.H.; Middleton, J. Orphan receptor GPR15/BOB is up-reguLated in rheumatoid arthritis. Cytokine 2014, 67, 53-59. [CrossRef]

14. Nguyen, L.P.; Pan, J.; Dinh, T.T.; Hadeiba, H.; O’Hara, E., 3rd; Ebtikar, A.; Hertweck, A.; Gökmen, M.R.; Lord, G.M.; Jenner, R.G.; et al. Role and species-specific expression of colon T cell homing receptor GPR15 in colitis. Nat. Immunol. 2015, 16, 207-213. [CrossRef] [PubMed]

15. Fischer, A.; Zundler, S.; Atreya, R.; Rath, T.; Voskens, C.; Hirschmann, S.; López-Posadas, R.; Watson, A.; Becker, C.; Schuler, G.; et al. Differential effects of $\alpha 4 \beta 7$ and GPR15 on homing of effector and reguLatory T cells from patients with UC to the inflamed gut in vivo. Gut 2015, 65, 1642-1664. [CrossRef] [PubMed]

16. Adamczyk, A.; Gageik, D.; Frede, A.; Pastille, E.; Hansen, W.; Rueffer, A.; Buer, J.; Büning, J.; Langhorst, J.; Westendorf, A.M. Differential expression of GPR15 on T cells during uLcerative colitis. JCI Insight 2017, $2,8$. [CrossRef] [PubMed]

17. Ammitzbøll, C.; Marina, R.; Börnsen, L.; Petersen, E.R.; McWilliam, O.; Ratzer, R.; Christensen, J.R.; Oturai, A.B.; Søndergaard, H.B.; Sellebjerg, F. GPR15 ${ }^{+}$T cells are Th17 like, increased in smokers and associated with multiple sclerosis. J. Autoimmun. 2018, 97, 114-121. [CrossRef] [PubMed]

18. Chen, C.; Wu, N.; Duan, Q.; Yang, H.; Wang, X.; Yang, P.; Zhang, M.; Liu, J.; Liu, Z.; Shao, Y.; et al. C10orf99 contributes to the development of psoriasis by promoting the proliferation of keratinocytes. Sci. Rep. 2018, 8 , 8590. [CrossRef] [PubMed]

19. Breitling, L.P.; Yang, R.; Korn, B.; Burwinkel, B.; Brenner, H. Tobacco-smoking-related differential DNA methylation: 27K discovery and replication. Am. J Hum. Genet. 2011, 88, 450-457. [CrossRef]

20. Wan, E.S.; Qiu, W.; Baccarelli, A.; Carey, V.J.; Bacherman, H.; Rennard, S.I.; Agusti, A.; Anderson, W.; Lomas, D.A.; DeMeo, D.L. Cigarette smoking behaviors and time since quitting are associated with differential DNA methylation across the human genome. Hum. Mol. Genet. 2012, 21, 3073-3082. [CrossRef]

21. Sun, Y.V.; Smith, A.K.; Conneely, K.N.; Chang, Q.; Li, W.; Lazarus, A.; Smith, J.A.; Almli, L.M.; Binder, E.B.; Klengel, T.; et al. Epigenomic association analysis identifies smoking-related DNA methylation sites in African Americans. Hum. Genet. 2013, 132, 1027-1037. [CrossRef]

22. Zeilinger, S.; Kuhnel, B.; Klopp, N.; Baurecht, H.; Kleinschmidt, A.; Gieger, C.; Weidinger, S.; Lattka, E.; Adamski, J.; Peters, A.; et al. Tobacco smoking leads to extensive genome-wide changes in DNA methylation. PLoS ONE 2013, 8, e63812. [CrossRef] 
23. Gao, X.; Jia, M.; Zhang, Y.; Breitling, L.P.; Brenner, H. DNA methylation changes of whole blood cells in response to active smoking exposure in aduLts: A systematic review of DNA methylation studies. Clin. Epigenet. 2015, 7, 113. [CrossRef]

24. Bauer, M.; Fink, B.; Thürmann, L.; Eszlinger, M.; Herberth, G.; Lehmann, I. Tobacco smoking differently influences cell types of the innate and adaptive immune system-indications from CpG site methylation. Clin. Epigenet. 2016, 8, 83. [CrossRef] [PubMed]

25. Bauer, M.; Linsel, G.; Fink, B.; Offenberg, K.; Hahn, A.M.; Sack, U.; Knaack, H.; Eszlinger, M.; Herberth, G. A varying $\mathrm{T}$ cell subtype explains apparent tobacco smoking induced single CpG hypomethylation in whole blood. Clin. Epigenet. 2015, 7, 81. [CrossRef] [PubMed]

26. Dogan, M.V.; Shields, B.; Cutrona, C.; Gao, L.; Gibbons, F.X.; Simons, R.; Monick, M.; Brody, G.H.; Tan, K.; Beach, S.R.; et al. The effect of smoking on DNA methylation of peripheral blood mononuclear cells from African American women. BMC Genom. 2014, 15, 151. [CrossRef] [PubMed]

27. Dogan, M.V.; Xiang, J.H.; Beach, S.R.H.; Cutrona, C.; Gibbons, F.X.; Simons, R.L.; Brody, G.H.; Stapleton, J.T.; Philibert, R.A. Ethnicity and smoking-associated DNA methylation changes at HIV co-receptor GPR15. Front. Psychiatry 2015, 6, 132. [CrossRef] [PubMed]

28. Joehanes, R.; Just, A.C.; Marioni, R.E.; Pilling, L.C.; Reynolds, L.M.; Mandaviya, P.R.; Guan, W.; Xu, T.; Elks, C.E.; Aslibekyan, S.; et al. Epigenetic Signatures of Cigarette Smoking. Circ. Cardiovasc. Genet. 2016, 9 , 436-447. [CrossRef] [PubMed]

29. Ladd-Acosta, C. Epigenetic Signatures as Biomarkers of Exposure. Curr. Environ. Health Rep. 2015, 2, 117-125. [CrossRef] [PubMed]

30. Andersen, A.; Dogan, M.; Beach, S.; Philibert, R. Current and Future Prospects for Epigenetic Biomarkers of Substance Use Disorders. Genes 2015, 6, 991-1022. [CrossRef] [PubMed]

31. Philibert, R.; Beach, S.R.; Lei, M.-K.; Brody, G.H. Changes in DNA methylation at the aryl hydrocarbon receptor repressor may be a new biomarker for smoking. Clin. Epigenet. 2013, 5, 19. [CrossRef]

32. Andersen, A.M.; Philibert, R.A.; Gibbons, F.X.; Simons, R.L.; Long, J. Accuracy and utility of an epigenetic biomarker for smoking in popuLations with varying rates of false self-report. Am. J. Med. Genet. Part B Neuropsychiatr. Genet. 2017, 174, 641-650. [CrossRef]

33. Philibert, R.; Dogan, M.V.; Noel, A.; Miller, S.; Krukow, B.; Papworth, E.; Cowley, J.; Long, J.D.; Beach, S.R.; Black, D.W. Dose response and prediction characteristics of a methylation sensitive digital PCR assay for cigarette consumption in aduLts. Front. Genet. Epigenet. 2018, 9, 137. [CrossRef]

34. Philibert, R.; Hollenbeck, N.; Andersen, E.; Osborn, T.; Gerrard, M.; Gibbons, F.X.; Wang, K. A quantitative epigenetic approach for the assessment of cigarette consumption. Front. Psychol. 2015, 6, 656. [CrossRef] [PubMed]

35. Marabita, F.; Almgren, M.; Sjöholm, L.K.; KuLar, L.; Liu, Y.; James, T.; Kiss, N.B.; Feinberg, A.P.; Olsson, T.; Kockum, I.; et al. Smoking induces DNA methylation changes in MuLtiple Sclerosis patients with exposure-response relationship. Sci. Rep. 2017, 7, 14589. [CrossRef] [PubMed]

36. Guida, F.; Sandanger, T.M.; Castagne, R.; Campanella, G.; Polidoro, S.; Palli, D.; Krogh, V.; Tumino, R.; Sacerdote, C.; Panico, S.; et al. Dynamics of smoking-induced genome-wide methylation changes with time since smoking cessation. Hum. Mol. Genet. 2015, 24, 2349-2359. [CrossRef] [PubMed]

37. Philibert, R.; Hollenbeck, N.; Andersen, E.; McElroy, S.; Wilson, S.; Vercande, K.; Beach, S.R.; Osborn, T.; Gerrard, M.; Gibbons, F.X.; et al. Reversion of AHRR demethylation is a quantitative biomarker of smoking cessation. Front. Psychiatry 2016, 7, 55. [CrossRef]

38. Tsaprouni, L.G.; Yang, T.P.; Bell, J.; Dick, K.J.; Kanoni, S.; Nisbet, J.; Viñuela, A.; Grundberg, E.; Nelson, C.P.; Meduri, E.; et al. Cigarette smoking reduces DNA methylation levels at muLtiple genomic loci but the effect is partially reversible upon cessation. Epigenetics 2014, 9, 1382-1396. [CrossRef]

39. Ambatipudi, S.; Cuenin, C.; Hernandez-Vargas, H.; Ghantous, A.; Le Calvez-Kelm, F.; Kaaks, R.; Barrdahl, M.; Boeing, H.; Aleksandrova, K.; Trichopoulou, A.; et al. Tobacco smoking-associated genome-wide DNA methylation changes in the EPIC study. Epigenomics 2016, 8, 599-618. [CrossRef]

40. Moir, D.; Rickert, W.S.; Levasseur, G.; Larose, Y.; Maertens, R.; White, P.; Desjardins, S. A comparison of mainstream and sidestream marijuana and tobacco cigarette smoke produced under two machine smoking conditions. Chem. Res. Toxicol. 2008, 21, 494-502. [CrossRef] 
41. Vogel, C.F.; Haarmann-Stemmann, T. The aryl hydrocarbon receptor repressor-more than a simple feedback inhibitor of AhR signaling: Clues for its role in inflammation and cancer. Curr. Opin. Toxicol. 2017, 2, 109-119. [CrossRef]

42. Ligthart, S.; Marzi, C.; Aslibekyan, S.; Mendelson, M.M.; Conneely, K.N.; Tanaka, T.; Colicino, E.; Waite, L.L.; Joehanes, R.; Guan, W.; et al. DNA methylation signatures of chronic low-grade inflammation are associated with complex diseases. Genome Biol. 2016, 17, 255. [CrossRef]

43. Zhang, Y.; Wilson, R.; Heiss, J.; Breitling, L.P.; Saum, K.-U.; Schöttker, B.; Holleczek, B.; Waldenberger, M.; Peters, A.; Brenner, H. DNA methylation signatures in peripheral blood strongly predict all-cause mortality. Nat. Commun. 2017, 8, 14617. [CrossRef]

44. Bojesen, S.E.; Timpson, N.; Relton, C.; Smith, D.G.; Nordestgaard, B.G. AHRR (cg05575921) hypomethylation marks smoking behaviour, morbidity and mortality. Thorax 2017, 72, 646-653. [CrossRef] [PubMed]

45. Bauer, M.; Hackermüller, J.; Schor, J.; Schreiber, S.; Fink, B.; Pierzchalski, A.; Herberth, G. Specific induction of the unique GPR15 expression in heterogeneous blood lymphocytes by tobacco smoking. Biomarkers 2019, 24, 217-224. [CrossRef] [PubMed]

46. Su, D.; Wang, X.; Campbell, M.R.; Porter, D.K.; Pittman, G.S.; Bennett, B.D.; Wan, M.; Englert, N.A.; Crowl, C.L.; Gimple, R.N.; et al. Distinct epigenetic effects of tobacco smoking in whole blood and among leukocyte subtypes. PLoS ONE 2016, 11, e0166486. [CrossRef] [PubMed]

47. Koks, G.; Uudelepp, M.L.; Limbach, M.; Peterson, P.; Reimann, E.; Koks, S. Smoking-induced expression of the GPR15 gene indicates its potential role in chronic inflammatory pathologies. Am. J. Pathol. 2015, 185, 2898-2906. [CrossRef]

48. Kim, S.V.; Xiang, W.V.; Kwak, C.; Yang, Y.; Lin, X.W.; Ota, M.; Sarpel, U.; Rifkin, D.B.; Xu, R.; Littman, D.R. GPR15-mediated homing controls immune homeostasis in the large intestine mucosa. Science 2013, 340, 1456-1459. [CrossRef]

49. Bauer, M.; Fink, B.; Seyfarth, H.-J.; Wirtz, H.; Frille, A. Tobacco-smoking induced GPR15-expressing T cells in blood do not indicate puLmonary damage. BMC Pulm. Med. 2017, 17, 159. [CrossRef]

50. Russo, E.B.; McPartland, J.M. Cannabis is more than simply $\Delta$ 9-tetrahydrocannabinol. Psychopharmacology 2003, 165, 431-432. [CrossRef]

51. Padgett, D.A.; Glaser, R. How stress influences the immune response. Trends Immunol. 2003, 24, 444-448. [CrossRef]

52. Steptoe, A.; Kunz-Ebrecht, S.; Brydon, L.; Wardle, J. Central adiposity and cortisol responses to waking in middle-aged men and women. Int. J. Obes. 2004, 28, 1168. [CrossRef]

53. Cho, J.Y. ImmunomoduLatory effect of nonsteroidal anti-inflammatory drugs (NSAIDs) at the clinically available doses. Arch. Pharmacal. Res. 2007, 30, 64. [CrossRef]

54. Kayani, N.; Homan, S.G.; Yun, S. Racial disparities in smoking-attributable mortality and years of potential life lost-Missouri, 2003-2007. Morb. Mortal. Wkly. Rep. 2010, 59, 1518-1522.

55. Haiman, C.A.; Stram, D.O.; Wilkens, L.R.; Pike, M.C.; Kolonel, L.N.; Henderson, B.E.; Le Marchand, L. Ethnic and racial differences in the smoking-related risk of lung cancer. N. Engl. J. Med. 2006, 354, 333-342. [CrossRef] [PubMed]

56. Paalani, M.; Lee, J.W.; Haddad, E.; Tonstad, S. Determinants of inflammatory markers in a bi-ethnic popuLation. Ethn. Dis. 2011, 21, 142. [PubMed]

57. Kogan, S.M.; Lei, M.K.; Grange, C.R.; Simons, R.L.; Brody, G.H.; Gibbons, F.X.; Chen, Y.F. The contribution of community and family contexts to African American young aduLts' romantic relationship health: A prospective analysis. J. Youth Adolesc. 2013, 42, 878-890. [CrossRef]

58. Simons, R.L.; Simons, L.G.; Lei, M.K.; Landor, A.M. Relational schemas, hostile romantic relationships, and beliefs about marriage among young African American aduLts. J. Soc. Pers. Relatsh. 2012, 29, 77-101. [CrossRef]

59. Simons, R.L.; Lei, M.-K.; Beach, S.R.; Barr, A.B.; Simons, L.G.; Gibbons, F.X.; Philibert, R.A. Discrimination, segregation, and chronic inflammation: Testing the weathering explanation for the poor health of Black Americans. Dev. Psychol. 2018, 54, 1993. [CrossRef]

60. Kroenke, K.; Spitzer, R.L.; Williams, J.B. The PHQ-9: Validity of a brief depression severity measure. J. Gen. Intern. Med. 2001, 16, 606-613. [CrossRef]

61. Cohen, S.; Kamarck, T.; Mermelstein, R. Perceived stress scale. Meas. Stress Guide Health Soc. Sci. 1994, 10, 235-283. 
62. Dandona, P.; Aljada, A.; Bandyopadhyay, A. Inflammation: The link between insulin resistance, obesity and diabetes. Trends Immun. 2004, 25, 4-7. [CrossRef]

63. Philibert, R.A.; Beach, S.R.; Brody, G.H. Demethylation of the aryl hydrocarbon receptor repressor as a biomarker for nascent smokers. Epigenetics 2012, 7, 1331-1338. [CrossRef]

64. RC Team. R: A Language and Environment for Statistical Computing; R Foundation for Statistical Computing: Vienna, Austria, 2012.

65. Chou, R.M.M.; Nakamoto, E.; Griffin, J. Analgesics for Osteoarthritis: An Update of the 2006 Comparative Effectiveness Review; Agency for Healthcare Research and Quality: Rockville, MD, USA, 2011.

66. Groemping, U.; Matthias, L. Package 'relaimpo'. 2018.

67. Visser, M.; Bouter, L.M.; McQuillan, G.M.; Wener, M.H.; Harris, T.B. Elevated C-reactive protein levels in overweight and obese aduLts. Jama 1999, 282, 2131-2135. [CrossRef] [PubMed]

68. Ford, E.S. Body mass index, diabetes, and C-reactive protein among US aduLts. Diabetes Care 1999, 22, 1971-1977. [CrossRef] [PubMed]

69. Beach, S.R.H.; Lei, M.K.; Ong, M.L.; Brody, G.H.; Dogan, M.V.; Philibert, R.A. MTHFR methylation moderates the impact of smoking on DNA methylation at AHRR for African American young aduLts. Am. J. Med. Genet. Part B Neuropsychiatr. Genet. 2017, 174, 608-618. [CrossRef] [PubMed]

70. Andersen, A.M.; Lei, M.K.; Philibert, R.; Beach, S. Methylation of MTHFR moderates the effect of smoking on genomewide methylation among middle age African Americans. Front. Genet. 2018, 9, 622. [CrossRef] [PubMed]

71. Houseman, E.A. DNA methylation and cell-type distribution. In Computational and Statistical Epigenomics; Teschendorff, A.E., Ed.; Translational Bioinformatics. 7; Springer: Dort, The Netherlands, 2015; pp. 35-50.

(C) 2020 by the authors. Licensee MDPI, Basel, Switzerland. This article is an open access article distributed under the terms and conditions of the Creative Commons Attribution (CC BY) license (http://creativecommons.org/licenses/by/4.0/). 